\title{
T Cell Receptor Repertoire of Infiltrating T Cells in Lips of Sjögren's Syndrome Patients
}

Takayuki Sumida, Fumiko Yonaha, Toshiro Maeda, Emiko Tanabe,* Takao Koike, Hisao Tomioka, and Sho Yoshida Second Department of Internal Medicine and *Department of Dermatology, School of Medicine, Chiba University, Chiba City, Chiba 280, Japan

\begin{abstract}
Infiltrating $T$ cells around salivary glands in the lips of Sjögren's syndrome (SjS) patients are crucial in the pathogenesis of this disease. To analyze the nature of infiltrating $T$ cells, their $T$ cell receptor repertoire was examined with quantitative polymerase chain reaction. The repertoire of $V \beta$ transcripts in lips of SjS was not restricted; however, the $V \beta 2$ and $V \beta 13$ genes were predominantly expressed on the $T$ cells of lip specimens in six and four of seven lips, respectively. Predominance of these genes was specific in lips because no predominant $\mathrm{V} \beta$ transcripts were found in lips from healthy subjects and PBLs from $\mathrm{SjS}$ patients. These results indicated that the $\mathrm{V} \beta 2$ - and V $\beta$ 13-positive $T$ cells expanded specifically and preferentially in $\mathrm{SjS}$ lips, thereby suggesting the possible role in triggering the autoimmunity of this disease. (J. Clin. Invest. 1992. 89:681-685.) Key words: autoreactive T cells • Sjögren's syndrome $\bullet T$ cell receptor $V \beta$ gene
\end{abstract}

\section{Introduction}

Sjögren's syndrome $(\mathrm{SjS})^{1}$ is an autoimmune disease characterized by lymphocytic infiltration of lacrimal and salivary glands, which leads to symptomatic dry eyes and mouth (1). Immunohistological studies $(2,3)$ have clarified that the majority of the infiltrating lymphocytes around salivary glands were CD4-positive $T$ cells and that CD8-positive $T$ cells were in the salivary duct epithelium. However, there have been no reports on the nature of the infiltrated $\mathrm{T}$ cells in the salivary glands of SjS patients.

Recently, the quantitative polymerase chain reaction (PCR) was established by Choi et al. (4) and may serve well in the rapid estimation of the human $T$ cell repertoire, as there are limited numbers of MAbs against at least 20 different $V \beta$ families in humans (5). In this paper, to examine the mechanism of autoimmunity of $\mathrm{SjS}$, we have analyzed the repertoire of $\mathrm{T}$ cell receptor (TCR) genes from infiltrating $T$ cells around salivary glands in lips of $\mathrm{SjS}$ patients by using quantitative PCR (6). We obtained evidence that the repertoire of TCR V $\beta$ gene on infil-

Address correspondence to Dr. Takayuki Sumida, Second Department of Internal Medicine, School of Medicine, Chiba University, 1-8-1 Inohana, Chiba City, Chiba, Japan 280.

Received for publication 14 February 1991 and in revised form $14 \mathrm{Au}$ gust 1991.

1. Abbreviations used in this paper: $\mathrm{PCR}$, polymerase chain reaction; $\mathrm{SjS}$, Sjögren's syndrome; TCR, T cell receptor.

J. Clin. Invest.

(c) The American Society for Clinical Investigation, Inc.

$0021-9738 / 92 / 02 / 0681 / 05 \$ 2.00$

Volume 89, February 1992, 681-685 trating $\mathrm{T}$ cells from lips in SjS patients was not restricted; however, the $\mathrm{V} \beta 2$ and $\mathrm{V} \beta 13$ genes were predominantly expressed in SjS lips. The possible role of these $\mathrm{T}$ cells in the progression of $\mathrm{SjS}$ is discussed.

Patients. Seven SjS patients were referred for study to the Chiba University Hospital and all met the definition for SjS. The criteria for the diagnosis included keratoconjunctivitis sicca, xerostomia, and mononuclear cell infiltration of the salivary gland in lip biopsy samples (grade 4) (7).

PCR and quantitation of TCR V $\beta$ gene transcripts. Total RNA (5$10 \mu \mathrm{g}$ ) was prepared by using RNA zol solution (Biotecx Laboratories Inc., East Houston, TX), from lip specimens of SjS patients that had obvious infiltrating $\mathrm{T}$ cells around salivary glands by histological studies (grade 4) or from normal control lip specimens (grade 0). cDNAs were synthesized in a $20-\mu$ l reaction mixture containing oligo(dT) primer by AMV reverse transcriptase from $5 \mu \mathrm{g}$ total RNA. Amplification was performed with Taq polymerase in $50 \mu$ lof standard buffer by use of $0.2 \mu \mathrm{l}$ of cDNA (corresponding to $50 \mathrm{ng}$ of total RNA) with 20 different $\mathrm{V} \beta$ and $\mathrm{C} \beta$ primers to detect each $\mathrm{V} \beta$ gene. The $\mathrm{cDNA}$ corresponding to 0.5 ng RNA was a suitable dose for PCR with the $5^{\prime}-\mathrm{C} \beta$ and $3^{\prime}-\mathrm{C} \beta$ primers to detect total $C \beta$ gene. The sequences of some $V \beta$ primers were from previously published reports (8), and the sequence for $C \beta$ primer was the common one in the $C \beta 1$ and $C \beta 2$ gene segments. Oligonucleotides were synthesized by DNA synthesizer (Applied Biosystems Inc., Foster City, CA). The denature step was carried out at $94^{\circ} \mathrm{C}$ for $1.5 \mathrm{~min}$, the annealing step at $60^{\circ} \mathrm{C}$ for $1 \mathrm{~min}$, and the extension step at $72^{\circ} \mathrm{C}$ for $1 \mathrm{~min}$ for 30 cycles on a DNA thermal cycler (Zymoreactor V2; Atto Co. Ltd., Japan). One-fifth of the sample was loaded on a $2 \%$ agarose gel with ethidium bromide, and amplified DNA bands (250-300 bp) bearing VDJC $\beta$ genes could be detected.

For quantitation of the TCR $\mathrm{V} \beta$ and $\mathrm{C} \beta$ gene transcripts, PCR products were hybridized with the ${ }^{32} \mathrm{P}$-labeled $\mathrm{Bg} 12$ fragment of the JUR- $\beta 2$ gene (9) (C $\beta)$ and the intensities of the autoradiographic bands were quantitated by densitometer (Fujix BAS 2000, Fujifilm I\&I Co.). The relative amounts of TCR $\mathrm{V} \beta$ and $\mathrm{C} \beta$ genes were calculated by using standardization curves. To make standardization curves, cDNAs from PBLs in healthy subjects were serially diluted (corresponding to 1 $\times 10^{5}$ pg RNA) and subjected to PCR with individual $\mathrm{V} \beta$ and $\mathrm{C} \beta$ primers, or $5^{\prime}-\mathrm{C} \beta$ and $3^{\prime}-\mathrm{C} \beta$ primers as a control for 30 cycles of $1.5 \mathrm{~min}$ at $94^{\circ} \mathrm{C}, 1 \mathrm{~min}$ at $60^{\circ} \mathrm{C}$, and $1 \mathrm{~min}$ at $72^{\circ} \mathrm{C}$. By using each standard curve, the relative amount of cDNAs encoding individual $\mathrm{V} \beta$ genes and total $\mathrm{C} \beta$ genes was calculated as RNA (cDNA) from PBL of healthy subjects, respectively. The $\mathrm{V} \beta$ gene expression was represented as $\mathrm{V} \beta / \mathrm{C} \beta(\%)$.

The cDNAs (corresponding to 3 ng RNA) from PBLs of SjS patients and from healthy individuals were used for PCR to estimate the expression of $\mathrm{V} \beta$ genes on PBLs, and hundredth amounts of each DNA (corresponding to $30 \mathrm{pg}$ RNA) were used to estimate the expression of $\mathrm{C} \beta$ genes.

Flow cytometry. PBLs from healthy subjects were isolated by FicollPaque separation. They were incubated with MAbs against V $\beta 8$ (16G8) or V $\beta 12$ gene products (S511) (T Cell Sciences Inc., Cambridge, MA) and then with FITC-conjugated goat anti-mouse Ig. They were washed and resuspended at a concentration of $10^{6} \mathrm{cells} / \mathrm{ml}$ and then analyzed 
by FACScan ${ }^{\oplus}$ (Becton Dickinson Immunocytometry Systems, Mountain View, CA).

\section{Results}

To examine the efficiency of the $V \beta$ primers, total RNA was prepared from healthy human PBLs and cDNAs were synthesized as described in Methods. The cDNAs encoding VDJC $\beta$ were amplified with individual sets of $\mathrm{V} \beta$ and $\mathrm{C} \beta$ primers. 20 different $\mathrm{V} \beta$-specific oligonucleotides representing human TCR V $\beta$ families were used for the 5'-primers, and a C $\beta$ sequence was used for the 3 '-primer (Table I). Each $\mathrm{V} \beta$-C $\beta$ primer yielded a band of $250-300$ bp as visualized with ethidium bromide by PCR, and amplified DNAs were further confirmed by hybridization with a radiolabeled $C \beta$ probe (9) as shown in Fig. 1. These results show that the PCR using each V $\beta$ primer and the $C \beta$ primer could amplify DNAs bearing individual VDJC $\beta$ genes. The PCR products encoding total $C \beta$ genes yielded a band of $388 \mathrm{bp}$, using $5^{\prime}-\mathrm{C} \beta$ and $3^{\prime}-\mathrm{C} \beta$ primers (Fig. 1).

For quantification of the $V \beta$ transcripts on the infiltrating $T$ cells in the lips of SjS patients, the following experiments were carried out: total RNA was prepared from seven lip biopsy specimens of $\mathrm{SjS}$ as well as from normal control lips, cDNAs were synthesized, and PCR was carried out. The amplified DNA products were hybridized with the ${ }^{32} \mathrm{P}$-labeled $\mathrm{C} \beta$ probe and the intensity of the radioactive bands was measured with a densitometer. The cDNAs encoding 20 different $\mathrm{V} \beta$ genes were quantitated by individual standardization curves that represented the relationship between the amount of cDNA used for

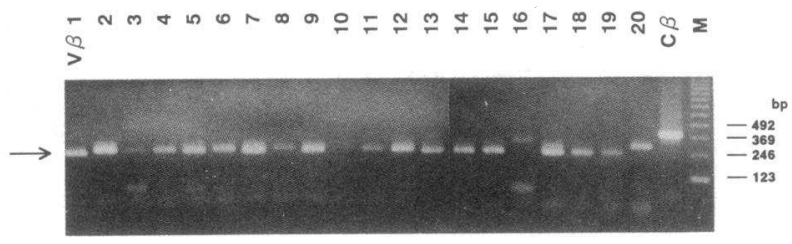

b

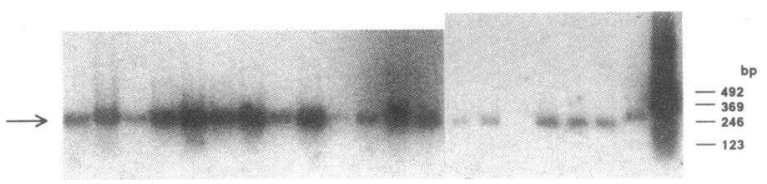

Figure 1. Detection of PCR-amplified products encoding TCR V $\beta$ on PBLs. (a) Total RNA $(20 \mu \mathrm{g})$ was prepared from PBLs of healthy individuals and was used for synthesis of cDNAs. The cDNAs corresponding to $200 \mathrm{ng}$ RNA were used for PCR to amplify DNAs encoding of TCR VDJC $\beta$ or $C \beta$ genes as described in Methods. One fifth of the amplified products was loaded on a $2 \%$ agarose gel with ethidium bromide, and amplified DNA bands (VDJC $\beta$ : 250-300 bp, arrow; $\mathrm{C} \beta: 388 \mathrm{bp}$ ) could be detected. (b) Amplified DNAs were hybridized with the ${ }^{32} \mathrm{P}-$ labeled $\mathrm{C} \beta$ probe. The signals correlated with the bands stained by ethidium bromide.

PCR and the radioactivity of PCR products (Fig. 2). To obtain the standardization curves, cDNAs from normal PBLs, were serially diluted and subjected to PCR and Southern blot analysis. When the radioactivity of each PCR product was plotted in

Table I. Sequence of Human T Cell Receptor Vß Primers

\begin{tabular}{|c|c|c|c|c|c|c|c|c|c|c|c|}
\hline \multirow{2}{*}{$\frac{\text { Primer }}{\mathrm{V} \beta 1}$} & \multicolumn{11}{|c|}{ Sequences } \\
\hline & $5^{\prime}$-TCT & AGA & ATT & $\mathrm{CCA}$ & AAA & GGA & AAC & ATT & CTT & GAA & $C-3^{\prime}$ \\
\hline $\mathrm{V} \beta 2$ & $5^{\prime}-\mathrm{TCT}$ & AGA & ATT & $\mathrm{CCC}$ & $\mathrm{ACA}$ & TAC & GAG & CAA & GGC & GTC & G-3' \\
\hline $\mathrm{V} \beta 3$ & $5^{\prime}$-TCT & AGA & ATT & CGA & AAA & AGG & AGA & TAT & $\mathrm{TCC}$ & TGA & G-3' \\
\hline $\mathrm{V} \beta 4$ & $5^{\prime}$-TCT & AGA & ATT & $\mathrm{CCA}$ & TAT & GAG & AGT & GGA & TTT & GTC & A-3' \\
\hline $\mathrm{V} \beta 5$ & 5'-TCT & AGA & ATT & CAA & AGG & AAA & CTT & $\mathrm{CCC}$ & TGG & TCG & A-3' \\
\hline $\mathrm{V} \beta 6$ & $5^{\prime}-\mathrm{TCT}$ & AGA & ATT & CAG & ATG & ACT & CAG & GGC & TGC & $\mathrm{CCA}$ & $A-3^{\prime}$ \\
\hline $\mathrm{V} \beta 7$ & 5'-TCT & AGA & ATT & CAG & TGT & GCC & AAG & TCG & CTT & CTC & $A-3^{\prime}$ \\
\hline $\mathrm{V} \beta 8$ & 5'-TCT & AGA & ATT & CAT & AGA & TGA & TTC & AGG & GAT & GCC & $C-3^{\prime}$ \\
\hline $\mathrm{V} \beta 9$ & 5'-TCT & AGA & ATT & CTG & AAA & CAG & TTC & CAA & ATC & GCT & $T-3^{\prime}$ \\
\hline $\mathrm{V} \beta 10$ & 5'-TCT & AGA & ATT & CAA & AGC & AGA & AAT & AAT & CAA & TGA & G-3' \\
\hline $\mathrm{V} \beta 11$ & 5'-TCT & AGA & ATT & CAA & GGG & AGA & TCT & TTC & СТC & TGA & G-3' \\
\hline $\mathrm{V} \beta 12$ & $5^{\prime}-\mathrm{TCT}$ & AGA & ATT & CAA & AGG & AGA & AGT & CTC & AGA & TGG & $C-3^{\prime}$ \\
\hline $\mathrm{V} \beta 13$ & 5'-TCT & AGA & ATT & CAT & GGC & TAC & AAT & GTC & TCC & AGA & $\mathrm{T}-3^{\prime}$ \\
\hline $\mathrm{V} \beta 14$ & 5'-TCT & AGA & ATT & CAA & GGG & AGA & TGT & TCC & TGA & AGG & G-3' \\
\hline $\mathrm{V} \beta 15$ & $5^{\prime}-\mathrm{TCT}$ & AGA & ATT & CAA & AGG & AGA & GAT & CTC & TGA & TGG & A-3' \\
\hline $\mathrm{V} \beta 16$ & $5^{\prime}$-TCT & AGA & ATT & CCT & TTA & TCG & ACG & TGT & TAT & GGG & A-3' \\
\hline $\mathrm{V} \beta 17$ & 5'-TCT & AGA & ATT & CGG & AGA & TAT & AGC & TGA & AGG & GTA & C- $3^{\prime}$ \\
\hline $\mathrm{V} \beta 18$ & $5^{\prime}-\mathrm{TCT}$ & AGA & ATT & CGG & AAT & GCC & AAA & GGA & ACG & ATT & T-3' \\
\hline $\mathrm{V} \beta 19$ & $5^{\prime}-\mathrm{TCT}$ & AGA & ATT & CGA & GAT & GCA & CAA & GAA & GCG & ATT & C-3' \\
\hline$V \beta 20$ & $5^{\prime}$-TCT & AGA & ATT & $\mathrm{CCT}$ & GCA & GGC & AGG & GGC & CTC & CAG & C-3' \\
\hline $\mathrm{C} \beta$ & $5^{\prime}-\mathrm{TCT}$ & AGA & ATT & CTT & CTG & ATG & GCT & CAA & ACA & C-3' & \\
\hline $5^{\prime}-\mathrm{C} \beta$ & $5^{\prime}-\mathrm{CCC}$ & ACA & $\mathrm{CCC}$ & AAA & AGG & CCA-3' & & & & & \\
\hline $3^{\prime}-\mathrm{C} \beta$ & $5^{\prime}$-CAT & AGA & GGA & TGG & TGG & CAG-3' & & & & & \\
\hline
\end{tabular}

The size of amplified products using $5^{\prime} \mathrm{V} \beta$ and $3^{\prime} \mathrm{C} \beta$ primers ranged from $\sim 250$ to $300 \mathrm{bp}$. Primers for $\mathrm{V} \beta$ and $\mathrm{C} \beta$ genes contained additional EcoRI and XbaI restriction enzyme sites for further cloning experiments. $5^{\prime}-\mathrm{C} \beta$ and $3^{\prime}-\mathrm{C} \beta$ primers were used to detect total $C \beta$ transcripts as internal control and yielded a band of $\sim 388 \mathrm{bp}$. 


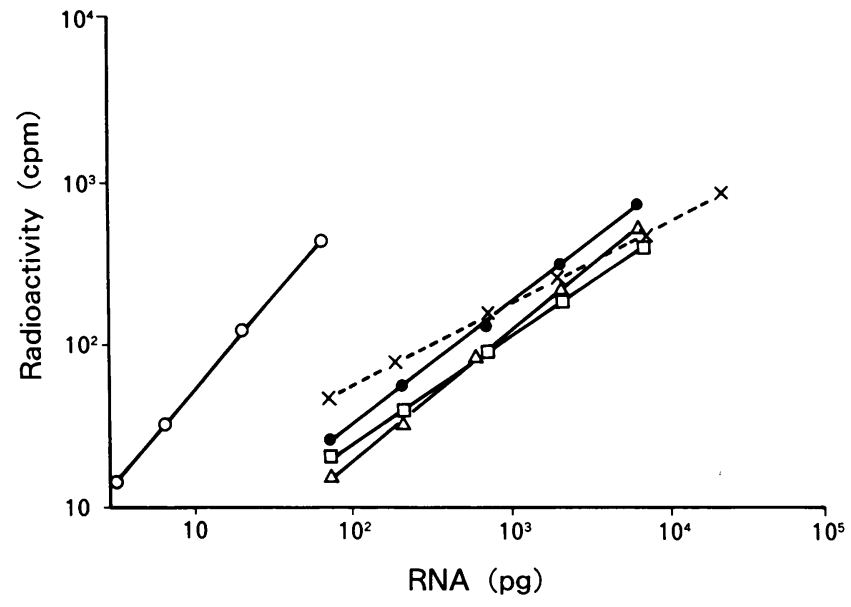

Figure 2. Standardization curves for quantitation of amplified products. The cDNAs from normal PBL were serially diluted (corresponding to $1 \times 10^{5} \mathrm{pg}$ RNA) and subjected to PCR with primers specific for 20 different individual $\mathrm{V} \beta$ and $\mathrm{C} \beta$ genes for 30 cycles of $1.5 \mathrm{~min}$ at $94^{\circ} \mathrm{C}, 1 \mathrm{~min}$ at $60^{\circ} \mathrm{C}$, and $1 \mathrm{~min}$ at $72^{\circ} \mathrm{C}$. Amplified DNAs were hybridized with the ${ }^{32} \mathrm{P}$-labeled $\mathrm{Bg} 12$ fragment of the JUR- $\beta 2$ gene and the intensities of autoradiographic bands were quantitated by densitometer. The radioactivity (cpm) in the $\mathrm{V} \beta$ or $\mathrm{C} \beta$ bands and the relative amount of cDNAs (RNA) encoding $\mathrm{V} \beta$ or $\mathrm{C} \beta$ genes used for PCR were plotted on a log-log graph. Here, the standard curves, including the $\mathrm{C} \beta(\mathrm{O}), \mathrm{V} \beta 2(\bullet), \mathrm{V} \beta 6(\square), \mathrm{V} \beta 7(\triangle)$, and $\mathrm{V} \beta 13(\times)$, are presented. a log-log graph against the amount of cDNA (RNA) encoding each individual $\mathrm{V} \beta$ gene, a linear relationship was obtained (Fig. 2). A linear relationship was also obtained in the case of the $\mathrm{C} \beta$ gene segment amplified with $5^{\prime}-\mathrm{C} \beta$ and $3^{\prime}-\mathrm{C} \beta$ primers, as a control. We used this system to quantify the amount of the cDNAs encoding $\mathrm{V} \beta$ and $\mathrm{C} \beta$ genes, respectively. The relative amount of $\mathrm{V} \beta$ gene expression was represented as $\mathrm{V} \beta / \mathrm{C} \beta(\%)$, because the infiltrating $\mathrm{T}$ cells in the individual lip biopsy samples were different in number.

Table II shows that the repertoire of TCR V $\beta$ gene in lips of SjS patients was not restricted; however, the $\mathrm{V} \beta 2$ gene (8.6$16.8 \%$ ) was predominantly detected in $\operatorname{six}(\mathrm{SjS} 8,9,10,11,12$, 14) of seven SjS lips compared with three lip specimens from healthy subjects $(2.3-4.8 \%)$. Additionally, the V $\beta 13$ gene was preferentially expressed (13.0-29.2\%) in four lips of SjS patients (SjS 8, 10,12,13) in comparison with normal lips (8.19.6\%). In some of the seven $\mathrm{SjS}$ lip samples examined, the other $\mathrm{V} \beta$ genes, such as $\mathrm{V} \beta 3,4,6,7,14$, or 18 , in addition to $\mathrm{V} \beta 2$ and $\mathrm{V} \beta 13$ genes, were preferentially expressed. In lips from healthy subjects without severe infiltration of T cells, total RNAs encoding TCR V $\beta$ and $C \beta$ gene were detectable, but their amount was 10 times less than in SjS lips.

The TCR V $\beta$ expression on PBLs of two SjS patients (SjS 10 and 12) was also estimated by the same method as in Table II. As shown in Fig. 3, the T cells expressing V $\beta 2$ (SjS 10: 8.6\%, SjS 12: 10.7\%) and $\mathrm{V} \beta 13$ genes (SjS 10: 20.9\%, SjS 12: 29.2\%)

Table II. TCR Vß Expression in Lip Specimens of SjS Patients

\begin{tabular}{|c|c|c|c|c|c|c|c|c|c|c|}
\hline \multirow{2}{*}{$\begin{array}{l}\text { Case } \\
\text { no. }\end{array}$} & \multicolumn{10}{|c|}{$\mathrm{V} \beta$ families $(\% \mathrm{~V} \beta / \mathrm{C} \beta)$} \\
\hline & 1 & 2 & 3 & 4 & 5 & 6 & 7 & 8 & 9 & 10 \\
\hline SjS 8 & 1.8 & 10.1 & 3.1 & 1.9 & 1.0 & 5.7 & 1.4 & 3.7 & 4.6 & 2.7 \\
\hline SjS 9 & 2.0 & 16.8 & 2.3 & 7.6 & 9.7 & 3.8 & 7.5 & 4.3 & 5.6 & 1.8 \\
\hline SjS 10 & 3.3 & 8.6 & 3.5 & 2.7 & 5.2 & 7.3 & 5.1 & 7.4 & 1.4 & 0.3 \\
\hline SjS 11 & 0.1 & 9.0 & 15.6 & 2.5 & 8.4 & 3.1 & 18.9 & 5.8 & 1.9 & 1.7 \\
\hline SjS 12 & 2.0 & 10.0 & 6.4 & 4.2 & 4.3 & 7.8 & 3.7 & 2.8 & 2.5 & 3.2 \\
\hline SjS 13 & 1.0 & 4.0 & 9.3 & 2.9 & 2.7 & 22.1 & 16.0 & 7.3 & 0.3 & 0.1 \\
\hline SjS 14 & 2.7 & 10.7 & 12.2 & 10.2 & 1.6 & 3.6 & 5.6 & 2.6 & 7.3 & 3.5 \\
\hline Control 1 & 1.2 & 4.8 & 8.8 & 4.6 & 3.9 & 7.2 & 5.6 & 4.9 & 2.6 & 1.2 \\
\hline Control 2 & 1.0 & 3.2 & 9.3 & 8.7 & 2.8 & 1.4 & 12.8 & 9.2 & 6.2 & 1.0 \\
\hline \multirow[t]{2}{*}{ Control 3} & 0.5 & 2.3 & 5.2 & 3.2 & 5.5 & 6.2 & 13.4 & 7.4 & 6.0 & 2.2 \\
\hline & \multicolumn{10}{|c|}{$\mathrm{V} \beta$ families $(\% \mathrm{~V} \beta / \mathrm{C} \beta)$} \\
\hline $\begin{array}{l}\text { nase } \\
\text { no. }\end{array}$ & 11 & 12 & 13 & 14 & 15 & 16 & 17 & 18 & 19 & 20 \\
\hline SjS 8 & 1.0 & 5.6 & 15.2 & 8.4 & 6.8 & 1.8 & 5.5 & 17.4 & 1.4 & 1.2 \\
\hline SjS 9 & 0.4 & 1.2 & 8.1 & 16.3 & 4.3 & 1.2 & 2.6 & 3.6 & 0.7 & 0.1 \\
\hline SjS 10 & 0.1 & 4.2 & 20.9 & 7.6 & 3.6 & 1.7 & 6.7 & 3.6 & 2.5 & 3.1 \\
\hline SjS 11 & 0.5 & 0.8 & 9.8 & 10.1 & 2.0 & 1.2 & 6.0 & 1.3 & 0.7 & 0.2 \\
\hline SjS 12 & 2.2 & 2.6 & 29.2 & 3.9 & 2.6 & 2.5 & 2.3 & 2.0 & 2.5 & 3.1 \\
\hline SjS 13 & 1.4 & 2.3 & 13.0 & 4.5 & 1.0 & 0.3 & 6.3 & 4.5 & 0.1 & 0.1 \\
\hline SjS 14 & 3.3 & 4.1 & 1.8 & 1.0 & 2.6 & 4.1 & 2.7 & 5.3 & 2.7 & 2.2 \\
\hline Control 1 & 2.1 & 2.9 & 9.1 & 7.2 & 8.2 & 2.9 & 7.8 & 6.8 & 4.3 & 3.8 \\
\hline Control 2 & 0.4 & 5.4 & 9.6 & 9.0 & 4.1 & 1.3 & 4.9 & 3.8 & 2.2 & 4.0 \\
\hline Control 3 & 2.0 & 4.6 & 8.1 & 9.6 & 5.6 & 4.0 & 4.4 & 5.8 & 3.1 & 1.0 \\
\hline
\end{tabular}

The cDNAs were synthesized by using $5 \mu \mathrm{g}$ total RNA from lip samples of SjS patients (grade 4 ) or healthy subjects (grade 0 ). The cDNAs corresponding to 50 or 0.5 ng RNA were used for PCR with $\mathrm{V} \beta$ and $\mathrm{C} \beta$ primers or $5^{\prime}-\mathrm{C} \beta$ and $3^{\prime}-\mathrm{C} \beta$ primers as described in Methods. The amplified DNAs were separated on a $2 \%$ agarose gel hybridized with the ${ }^{32} \mathrm{P}$-labeled $\mathrm{Bg} 12$ fragment of the JUR- $\beta 2$ gene. The intensities of the autoradiographic bands were quantitated by densitometer, and the $\mathrm{cDNAs}$ encoding $\mathrm{V} \beta$ and $\mathrm{C} \beta$ gene segments were calculated by using the respective standardizing curves (Fig. 2). The relative amount of TCR V $\beta$ transcripts was described as the $\mathrm{V} \beta / \mathrm{C} \beta$ ratio (\%). The percentage of T cells in PCR was the mean of two individual experiments. 


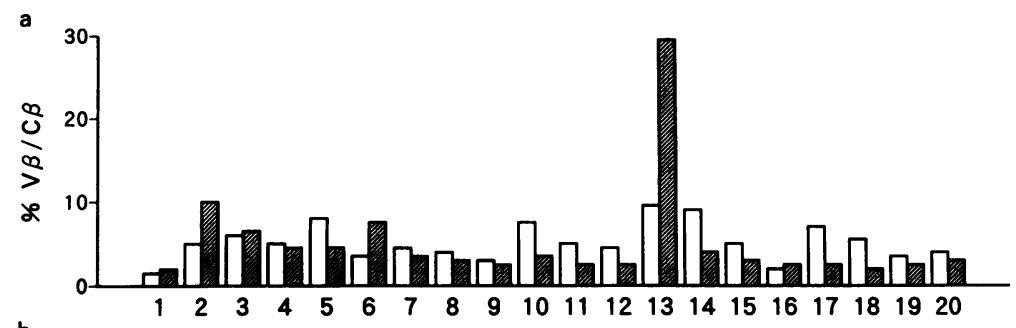

b

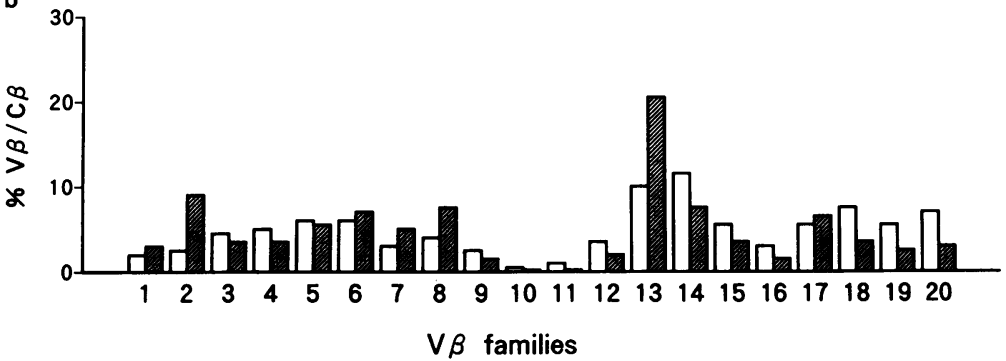

Figure 3. Expression of $\mathrm{V} \beta$ genes in lips and on PBLs of SjS patients. To estimate the $\mathrm{V} \beta$ gene expression, the cDNAs (corresponding to 3 ng RNA) from PBLs of two SjS patients $(a) \mathrm{SjS} 12(b) \mathrm{SjS} 10$ and cDNAs (corresponding to $50 \mathrm{ng}$ RNA) from lips of the same subjects were used for PCR, respectively, as described in Table II. For the $\mathrm{C} \beta$ gene, hundredth amounts of each cDNA were subjected to PCR. The relative amount of TCR V $\beta$

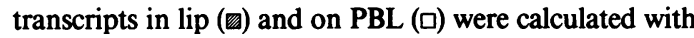
the same method as in Table II. The percentage of $T$ cells in PCR was the mean of two individual experiments. in lips from $\mathrm{SjS} 10$ and $\mathrm{SjS} 12$ patients increased in number compared with findings in PBLs from the same patients ( $\mathrm{V} \beta 2$ : 2.6 and $4.7 \% ; \mathrm{V} \beta 13: 9.9$ and $9.1 \%$, respectively). These results indicate that the $\mathrm{T}$ cells expressing $\mathrm{V} \beta 2$ and $\mathrm{V} \beta 13$ genes expanded specifically in the lips of $\mathrm{SjS}$ patients.

To confirm the results obtained by the quantitative PCR, we examined the actual percentage of $T$ cells expressing $V \beta 8$ and $\mathrm{V} \beta 12$ molecules on PBLs from the same three healthy subjects by using flow cytometry and anti-V $\beta$ MAbs. The data show that the percentages of $\mathrm{V} \beta 8(4.9 \pm 0.50 \%$, mean $\pm \mathrm{SD})$ - and $\mathrm{V} \beta 12(2.1 \pm 0.68 \%)$-positive $\mathrm{T}$ cells calculated by quantitative PCR were similar to those estimated by flow cytometry (V $\beta 8$ : 4.1 $\pm 0.24, \mathrm{~V} \beta 12: 2.4 \pm 0.81 \%)$.

\section{Discussion}

The TCR V $\beta$ repertoire of infiltrating T cells in lips of SjS patients was examined with the quantitative PCR method. We obtained evidence that the repertoire of $\mathrm{V} \beta$ transcripts was not restricted; however, the $\mathrm{V} \beta 2(8.6-16.8 \%)$ and $\mathrm{V} \beta 13$ (13.0$29.5 \%$ ) genes were predominantly expressed on $\mathrm{T}$ cells in SjS lips. Predominance of the $\mathrm{V} \beta 2$ and $\mathrm{V} \beta 13$ genes was specific in lips because lesser percentages of these two genes were expressed on PBLs ( $\mathrm{V} \beta 2: 2.6-4.7 \%, \mathrm{~V} \beta 13: 9.1-9.2 \%)$ in the same subjects. Thus, $\mathrm{T}$ cells bearing $\mathrm{V} \beta 2$ or $\mathrm{V} \beta 13$ genes may be responsible for triggering the autoimmunity of this disease.

Studies (10-13) of human autoimmune diseases have provided some evidence for oligoclonality by the restriction fragment length polymorphism method in patients with myasthenia gravis, multiple sclerosis, and rheumatoid arthritis. Indeed, Oksenberg et al. (14), using PCR technology with brain biopsy specimens, reported that TCR V $\alpha 10$ gene was preferentially expressed, suggesting the limited heterogeneity of TCR V $\alpha$ transcripts in brains of multiple sclerosis patients. Sottini et al. (15) demonstrated that synovial fluid $\mathrm{T}$ cells expressed $\mathrm{V} \beta 7$ transcripts and nonrestricted $V \alpha$ elements. The study in this paper is the first report on the TCR V $\beta$ repertoire of infiltrating $\mathrm{T}$ cells in lips of SjS patients.

Choi et al. (4) reported that $\mathrm{T}$ cells expressing certain $\mathrm{V} \beta$ genes could be stimulated by some bacterial toxins, such as toxic-shock syndrome toxin and staphylococcal enterotoxin, as a "superantigen." It is interesting to note that $\mathrm{V} \beta 2$-positive $\mathrm{T}$ cells can be stimulated by toxic-shock syndrome toxin 1 and $\mathrm{T}$ cells bearing $\mathrm{V} \beta 13$ gene expand by the stimulation of staphylococcal enterotoxin $\mathrm{C} 2$. This suggested the possibility that previous bacterial infection in the lips of SjS patients led to stimulation and expansion of $\mathrm{T}$ cells expressing these two genes. Some of these $\mathrm{T}$ cells might recognize self-antigens and play a crucial role in the pathogenesis of autoimmunity.

The self-antigens in SjS have not yet been identified, but an association between retrovirus infection and $\mathrm{SjS}$ has been suspected (16-18). Antibodies against HIV-1 protein were highly detected in the serum of SjS patients (16), and transgenic mice expressing the human T cell leukemia virus (HTLV-1) tax gene developed an exocrinopathy resembling SjS (17). Recently, a human intracisternal A-type retroviral particle was detected in lymphoblastoid cells exposed to homogenates of salivary tissue from $\mathrm{SjS}$ patients (18). These studies suggest the possibility that the retroviral particle by itself, or virus-induced products, might be candidates for self-antigens in the progression of SjS. The analysis of the antigen recognized by limited autoreactive $\mathrm{T}$ cells in the lips of SjS patients may prove to clarify the mechanism of autoimmunity in SjS.

Several investigations (19-21) of the TCR gene expression in animal models for $T$ cell-mediated autoimmune diseases, such as experimental allergic encephalomyelitis and collageninduced arthritis, have also demonstrated that the TCR gene usage involved in autoimmunity was restricted. In the case of experimental allergic encephalomyelitis, the administration of a MAb specific for the predominant $\mathrm{V} \beta 8$ molecules resulted in nearly complete prevention of the disease $(19,20)$. In addition, the vaccination of a synthetic peptide encoding for the hypervariable region of $\mathrm{V} \beta 8$ regions protected against encephalitis (22). Therefore, our results may indicate a new therapeutic approach to autoimmune diseases such as $\mathrm{SjS}$ by means of the selective elimination of predominant $\mathrm{T}$ cells in involved tissues by anti-TCR antibodies or the vaccination of peptides for TCR.

\section{Acknowledgments}

JUR- $\beta 2$ gene was kindly provided by Prof. Tak. W. Mak.

This work was supported in part by The Mochida Memorial Foundation for Medical and Pharmaceutical Research. Takayuki Sumida was supported as a postdoctoral fellow by the Japan Health Sciences Foundation. 


\section{References}

1. Bloch, K. J., W. W. Buchanan, M. J. Wohl, and J. J. Bunim. 1965. Sjögren's syndrome. A clinical, pathological and serological study of sixty-two cases. Medicine. 44:187-231.

2. Fox, R. I., T. C. Adamson III, S. Fong, C. Young, and F. V. Howell. 1983. Characterization of the phenotype and function of lymphocytes infiltrating the salivary gland in patients with primary Sjögren's syndrome. Diagn. Immunol. 1:233-239.

3. Adamson, T. C., III, R. I. Fox, D. M. Frisman, and F. V. Howell. 1983. Immunohistologic analysis of lymphoid infiltrates in primary Sjögren's syndrome using monoclonal antibodies. J. Immunol. 130:203-208.

4. Choi, Y., B. Kotzin, L. Herron, J. Callahan, P. Marrack, and J. Kappler. 1989. Interaction of Staphylococcus aureus toxin "superantigens" with human T cells. Proc. Natl. Acad. Sci. USA. 86:8941-8945.

5. Toyonaga, B., and T. W. Mak. 1987. Genes of the t-cell antigen receptor in normal and malignant T cells. Annu. Rev. Immunol. 5:585-620.

6. Saiki, R. K., S. Scharf, F. Faloona, K. B. Mullis, G. T. Horn, H. A. Erlich, and $\mathrm{N}$. Arnheim. 1985. Enzymatic amplification of $\beta$-globin genomic sequences and restriction site analysis for diagnosis of sickle cell anemia. Science (Wash. DC). 230:1350-1354

7. Chisholm, D. M., and D. K. Mason. 1968. Labial salivary gland biopsy in Sjögren's disease. J. Clin. Pathol. (Lond.). 21:656-660.

8. Wucherpfennig, K. W., K. Ota, N. Endo, J. G. Seidman, A. Rosenzweig H. L. Weiner, and D. A. Hafler. 1990. Shared human T cell receptor V $\beta$ usage to immunodominant regions of myelin basic protein. Science (Wash. DC). 248:1016-1019.

9. Yoshikai, Y., D. Anatoniou, S. P. Clark, Y. Yanagi, R. Sangster, P. V. Elsen, C. Terhorst, and T. W. Mak. 1984. Sequence and expression of transcripts of the human T-cell receptor $\beta$-chain genes. Nature (Lond.) 312:521-524.

10. Oksenberg, J. G., M. Sherritt, A. B. Begovich, H. A. Erlich, C. C. Bernard, L. L. Cavalli-Sfurze, and L. Steinman. 1989. T-cell receptor $\mathrm{V} \alpha$ and $\mathrm{C} \alpha$ alleles associated with multiple sclerosis and myasthemia gravis. Proc. Natl. Acad. Sci. USA. 86:988-992.

11. Beall, S. S., P. Concannon, P. Charmley, H. F. McFarland, R. A. Gatti, L. E. Hood, D. E. McFarlin, and W. E. Biddison. 1989. The germline repertoire of $T$ cell receptor $\beta$-chain genes in patients with chronic progressive multiple sclerosis. J. Neuroimmunol. 21:59-66.
12. Hafler, D. A., A. D. Duby, S. J. Lee, D. Benjamin, J. G. Seidman, and H. L. Weiner. 1988. Oligoclonal T lymphocytes in the cerebrospinal fluid of patients with multiple sclerosis. J. Exp. Med. 167:1313-1322.

13. Stamenkovic, I., M. Stegagno, K. A. Wright, S. M. Krane, E. P. Amento, R. B. Colvin, R. J. Duquesnoy, and J. T. Kurnick. 1988. Clonal dominance among T-lymphocyte infiltrates in arthritis. Proc. Natl. Acad. Sci. USA. 85:11791183.

14. Oksenberg, J. R., S. Stuart, A. B. Begovich, R. B. Bell, H. A. Erlich, L. Steinmann, and C. C. A. Bernard. 1990. Limited heterogeneity of rearranged $\mathrm{T}$-cell receptor $\mathrm{V} \alpha$ transcripts in brains of multiple sclerosis patients. Nature (Lond.). 345:344-346.

15. Sottini, A., L. Imberti, R. Gorla, R. Cattaneo, and D. Primi. 1991. Restricted expression of $\mathrm{T}$ cell receptor $\mathrm{V} \beta$ but not $\mathrm{V} \alpha$ genes in rheumatoid arthritis. Eur. J. Immunol. 21:451-466.

16. Talal, N., M. J. Dauphinee, H. Dang, S. S. Alexander, D. J. Hart, and R. F. Garry. 1990. Detection of serum antibodies to retroviral proteins in patients with primary Sjogren's syndrome (autoimmune exocrinopathy). Arthritis Rheum. 33:774-781.

17. Green, J. E., S. H. Hinrichs, J. Vogel, and G. Jay. 1989. Exocrinopathy resembling Sjögren's syndrome in HTLV-1 tax transgenic mice. Nature (Lond.) 341:72-74.

18. Garry, R. F., C. D. Fermin, D. J. Hart, S.-S. Alexander, L. A. Donehower, and H. Luo-Zhang. 1990. Detection of a human intracisternal A-type retrovira particle antigenically related to HIV. Science (Wash. DC). 250:1127-1129.

19. Archa-Orbea, H., D. J. Mitchell, L. Timmermann, D. C. Wraith, G. S. Tansch, M. K. Waldor, S. S. Zamvil, H. D. McDevitt, and L. Steinman. 1988 Limited heterogeneity of $\mathrm{T}$ cell receptors from lymphocytes mediating autoimmune encephalomyelitis allows specific immune intervention. Cell. 54:263-273

20. Urban, J. L., V. Kumar, D. H. Kono, C. Gomez, S. J. Horvath, J. Clayton, D. G. Ando, E. E. Sercarz, and L. Hood. 1988. Restricted use of T cell receptor V genes in murine autoimmune encephalomyelitis raises possibilities for antibody therapy. Cell. 54:577-592.

21. Wraith, D. C., H. D. McDevitt, L. Steinman, and H. Acha-Orbea. 1989. T cell recognition as the target for immune intervention in autoimmune disease. Cell. 57:709-715.

22. Vandenbark, A. A., G. Hashim, and H. Offner. 1989. Immunization with a synthetic T-cell receptor $\mathrm{V}$-region peptide protects against experimental autoimmune encephalomyelitis. Nature (Lond.). 341:541-544. 